\title{
ENERGY MANAGEMENT STUDY OF BOILER IN AN ALCOHOL REFINING FACTORY IN ETHIOPIA
}

\section{SAMUEL G. MARIAM \& SANKARANARAYANAN. G}

Faculty, Somcme, Adama Science and Technology University, Adama, Ethiopia

Energy Audit is a systematic approach to decision-making in the area of energy management. An energy audit is to identify the opportunities to reduce energy expenses applicable to domestic or industrial. It attempts to balance the total energy inputs with its use, and serves to identify all the energy streams in a facility.

Energy is one of the major factors for the economic development of a nation. In case of developing countries the energy sector gains attraction and importance [7, 8] in view of ever increasing energy need to match the increasing population. This sector needs huge investments, business opportunities and more employment. To meet global competition one area of focus is to reduce the cost of the product/ adopting Green or Eco policies for project without compromising customer satisfaction. The customer is satisfied only when the overall cost of the project is less and less operational procedure and least maintenance. The energy audit plays a role to [1,2] analyze energy efficiency, optimizing the operational parameters, best operating, economic operational conditions and mode of conservation of energy.
\end{abstract}

The study was made in an Alcohol Refining Factory, wherein nine energy consuming systems were identified and standard energy audits were done for pumps, compressors, boiler, distillery columns and prime movers. This paper deals with the energy audit carried out for the boiler in detail and the outcome. The result showed that nearly 258kL per annum on fuel expenses could be saved. The suitable methods or suggestions were recommended to the authorities in the industry to improvise on a few areas such as water treatment plant, enhancing the percentage of excess air and replacing the existing boiler with matching sized boiler as the industry needed.

KEYWORDS: Energy, Energy Audit, Steam Generation, Power Plant \& Economics

Received: Aug 31, 2017; Accepted: Sep 16, 2017; Published: Sep 27, 2017; Paper Id.: IJMPERDOCT201726

\section{INTRODUCTION}

Energy is the capacity to do work and work is the transfer of energy from one form to another form of energy. Energy sources are available as electrical, thermal, light, chemical, mechanical, solar, wind, tidal, nuclear energy and so on. The coal and the crude fuel are the major natural resources are meeting $85 \%$ of the society need which will deplete soon. The fundamental goal of energy management is to produce goods and provide services with the least cost and least environmental effect. The term energy management means many things to many people. The simple definition is" The judicious and effective use of energy to maximize profits (minimize costs) and enhance competitive positions" (Cape Hart, Turner and Kennedy).

Energy audits thus highlight the [1] Plant Energy Performance Plant energy performance (PEP) is the measure of whether a plant is now utilizing more to produce the products than in the previous years rather it is a measure of how well the energy management is effectively applied in practice. It compares the change in energy 
consumption from one year to the other years. The energy audit $[4,5]$ experts look into the energy conversation opportunities in an organization such as *fuel substitution *energy generation *energy distribution * energy usage process * techno- Economic feasibility.

Further. It is analyzed with a commonly used unit for documentation.

To allow comparison of energy quantities, these must be converted to a common unit of energy such as kWh, Giga joules, kCals etc.

Table 1: Commonly used Units in Energy Audit

\begin{tabular}{|c|l|c|}
\hline SI No. & \multicolumn{1}{|c|}{ Energy Quantity } & The unit used \\
\hline 1 & Electricity $(1 \mathrm{kWh})$ & $860 \mathrm{kCal} / \mathrm{kWh}(0.0036 \mathrm{GJ})$ \\
\hline 2 & Heavy fuel oil (Gross calorific value, GCV) GJ/ton) & $10000 \mathrm{kCal} / \mathrm{liter}(0.0411 \mathrm{GJ} / \mathrm{liter})$ \\
\hline 3 & Coal (Gross calorific value, GCV) & $4000 \mathrm{kCal} / \mathrm{kg}(28 \mathrm{GJ} / \mathrm{ton})$ \\
\hline
\end{tabular}

The Benchmark Parameters are shown Below

- $\mathrm{kWh} / \mathrm{MT}$ clinker or cement produced (cement plant)

- $\mathrm{kWh} / \mathrm{kg}$ yarn produced (Textile unit)

- $\mathrm{kWh} / \mathrm{MT}, \mathrm{kCal} / \mathrm{kg}$, paper produced (Paper plant)

- $\mathrm{kCal} / \mathrm{kWh}$ Power produced (Heat rate of a power plant)

- Million kilocals/MT Urea or Ammonia (Fertilizer plant)

- $\quad \mathrm{kWh} / \mathrm{MT}$ of liquid metal output (in a foundry)

\section{Equipment / Utility Related}

- $\mathrm{kW} /$ ton of refrigeration (Air conditioning plant)

- $\%$ thermal efficiency of a boiler plant

- $\%$ cooling tower effectiveness in a cooling tower

- $\mathrm{kWh} / \mathrm{NM}^{3}$ of compressed air generated

- $\mathrm{kWh} /$ litre in a diesel power generation plant. While such benchmarks are referred to, related crucial process.

- The crucial process parameters need mentioning for $[1,2]$ meaningful comparison among peers. For instance,

- For a cement plant - type of cement, Blaine number (fineness) i.e. Portland and the process used (wet/dry) are to be reported alongside $\mathrm{kWh} / \mathrm{MT}$ figure.

- For a textile unit - average count, type of yarn i.e. polyester/cotton, is to be reported alongside $\mathrm{kWh} / \mathrm{square}$ meter.

- For a paper plant - paper type, raw material (recycling extent), GSM quality is some important factors to be reported along with $\mathrm{kWh} / \mathrm{MT}, \mathrm{kCal} / \mathrm{kg}$ figures.

- For a power plant / cogeneration plant - plant \% loading, condenser vacuum, inlet cooling water temperature, would be important factors to be mentioned alongside heat rate $(\mathrm{kCal} / \mathrm{kWh})$. 
- For a fertilizer plant - capacity utilization $(\%)$ and on-stream factor is two inputs worth comparing while mentioning specific energy consumption

- For a foundry unit - melt output, furnace type, composition (mild steel, high carbon steel/cast iron, etc.) raw material mix, number or power trips could be some useful operating parameters to be reported while mentioning specific energy consumption data.

- For an Air conditioning (A/c) plant - Chilled water temperature level and refrigeration load (TR) is crucial for comparing $\mathrm{kW} / \mathrm{TR}$.

- For a boiler plant - fuel quality, type, steam pressure, temperature, flow, is useful comparators alongside thermal efficiency and more importantly, whether thermal efficiency is on the gross calorific value basis or net calorific value basis or whether the computation is by direct method or indirect heat loss method may mean a lot in benchmarking exercise for meaningful comparison.

- Cooling tower effectiveness - ambient air wet/dry bulb temperature, relative humidity, air and circulating water flows are required to be reported to make meaningful sense.

- Compressed air specific power consumption - is to be compared at a similar inlet air temperature and pressure of generating.

- Diesel power plant performance - is to be compared at similar loading \%, steady run condition etc.

The audit report include a description of energy inputs and product outputs by major department or by major processing function, and will evaluate the efficiency of each step of the manufacturing process. The means of improving these efficiencies will be listed, and at least a preliminary assessment of the cost of the improvements will be made to indicate the expected payback on any capital investment needed. The audit report should conclude with specific detailed recommendations for engineering studies and feasibility analysis, which must then be performed to justify the implementation of those conservation measures that require investments. The study was conducted in Ethiopia the currency used is called as Birr and in US DOLLAR, 1 USD = 23.49 Birr. The economic cost calculations are shown in Birr.

\section{DETAILS OF THE PLANT}

The Mekanissa Alcohol Factory, Addis Ababa a Government factory 15 year old, which produces 26 million liters of potable alcohol per year.

It is important to understand the construction and working of a boiler. It is made of rolled steel plate. A boiler is an enclosed vessel that provides a means for combustion and transfers heat to water until it becomes hot water or steam. The hot water or steam under pressure is then usable for transferring the heat to a process. Main classification of boiler two types of boilers

- $\quad$ Fire tube boilers.

- Water tube boilers

The various factors affecting the boiler performance are listed below: $f$ Periodical cleaning of boilers $f$ Periodical soot blowing $f$ Proper water treatment programme and blow down control $f$ Draft control $f$ Excess air control $f$ Percentage 
loading of boiler $f$ Steam generation pressure and temperature $f$ Boiler insulation $f$ Quality of fuel

Water is useful and cheap medium for transferring heat to a process. When water is boiled into steam its volume increases about 1,600 times, producing a force that is almost as explosive as gunpowder. This causes the boiler to be extremely dangerous equipment and should be treated and operated by trained, authorized boiler operators carefully. Liquid when heated up to the gaseous state this process is called evaporation. The heating surface is any part of the boiler; hot gases of combustion are on one side and water on the other.

Table 2: Specification of the Boiler in Use

\begin{tabular}{|c|c|}
\hline \multicolumn{2}{|c|}{ Specification } \\
\hline $\begin{array}{l}\text { 1.Types of the boiler is SM/FB } 300 / 15 / \mathrm{N} / 2 \mathrm{P}-\mathrm{R} / \mathrm{ELLO} \\
\text { fire tube steam-generator } \\
\text { 2.Fabricated in } 2000 \\
\text { 3. The capacity of boiler is } 3 \mathrm{ton} / \mathrm{hr} \\
\text { 4.Designed pressure is } 14 \mathrm{bar} \\
\text { 5.Steam temperature } 175^{\circ} \mathrm{C} \\
\text { 6. Outside length and diameter of the boiler is } 4.5 \mathrm{~m} \text { and } \\
\text { 1.75m respectively } \\
\text { 7.Drum: thickens } 16.25 \mathrm{~mm} \text {, length } 3960 \mathrm{~mm} \text { and } \\
\text { diameter } 1195 \mathrm{~mm} \\
\text { 8.Use furnace oil } \\
\text { 9.Oil and feed water are pre heated } 120{ }^{O} \mathrm{C} \text { and } 80{ }^{O} \mathrm{C} \\
\text { respectively } \\
\text { 10.Stem pressure and temperature at the out let of boiler } \\
\text { is } 8 \text { bar and } 175{ }^{O} C \text { respectively } \\
\text { 11. In the fire tube are placed tabulators that determine a } \\
\text { high turbulence flue gases movement. } \\
\text { 12. The steam separator is of multiple slots type }\end{array}$ & $\begin{array}{l}\text { 13. Front smoke box and front cover is divided } \\
\text { in demountable sectors. } \\
\text { 14.The front smoke box is provided with a } \\
\text { coupling flange for the connection to the } \\
\text { stack and a cleaning door } \\
\text { 15.The boiler is provided with fuel pump } \\
\text { motor and water pump motor } \\
\text { a. Fuel pump motor } \\
\text { I. Fabricated in } 1998 \\
\text { II. } \quad \text { Type BRONZONL } \\
\text { III. Serial No } 0129709 \\
\text { IV. Capacity } 11 \mathrm{~kW}, 3 \text { phase, } 50 \\
\text { 16. Water pump motor } \\
\text { 17. Yr of Mfg: Fab. in } 1998 \\
\text { 18. Type : ST132 MAZ } \\
\text { 19. Sl No : } 5224703 \\
\text { 20. Capacity : } 12 \mathrm{~kW} \text {, Frequency } 50 \mathrm{~Hz} \text {, } \\
\text { Voltage } 380 \mathrm{v}\end{array}$ \\
\hline
\end{tabular}

Any part of the boiler metal that actually contributes to make steam is the heating surface. The amount of heating surface of a boiler is expressed in square meters. The larger the heating surface a boiler has, the more efficient it becomes. The boiler has necessary mountings [mandatory] and required accessories. The paper deals with the energy audit on conservation of Energy of a boiler and also to find the Energy conservation opportunities [ECO], so as to reduce energy cost and prepare documents.

The Methodology adopted here [7, 8]

- $\quad$ Literature review,

- Preliminary data collection,

- Inspection of factory energy consumption records, systems and equipments.

- Data analysis

- Identify the feasibility of energy conservation opportunities.

The study was carried out as 


\section{Preliminary Energy Audit}

In which the details of energy consumption, estimation of scope for saving, identifying the area of study, identifies the immediate area of focus and identify the area where detailed study to be done.

\section{Detailed Energy Audit}

A detailed energy audit done in major systems using energy balance, based inventory of systems used, observation, calculations of energy use and energy loss.

The figure 1.0 shows the layout of the factory, which clearly shows the arrangement of various equipments connected in the production process. There are ways to study and improve certain system

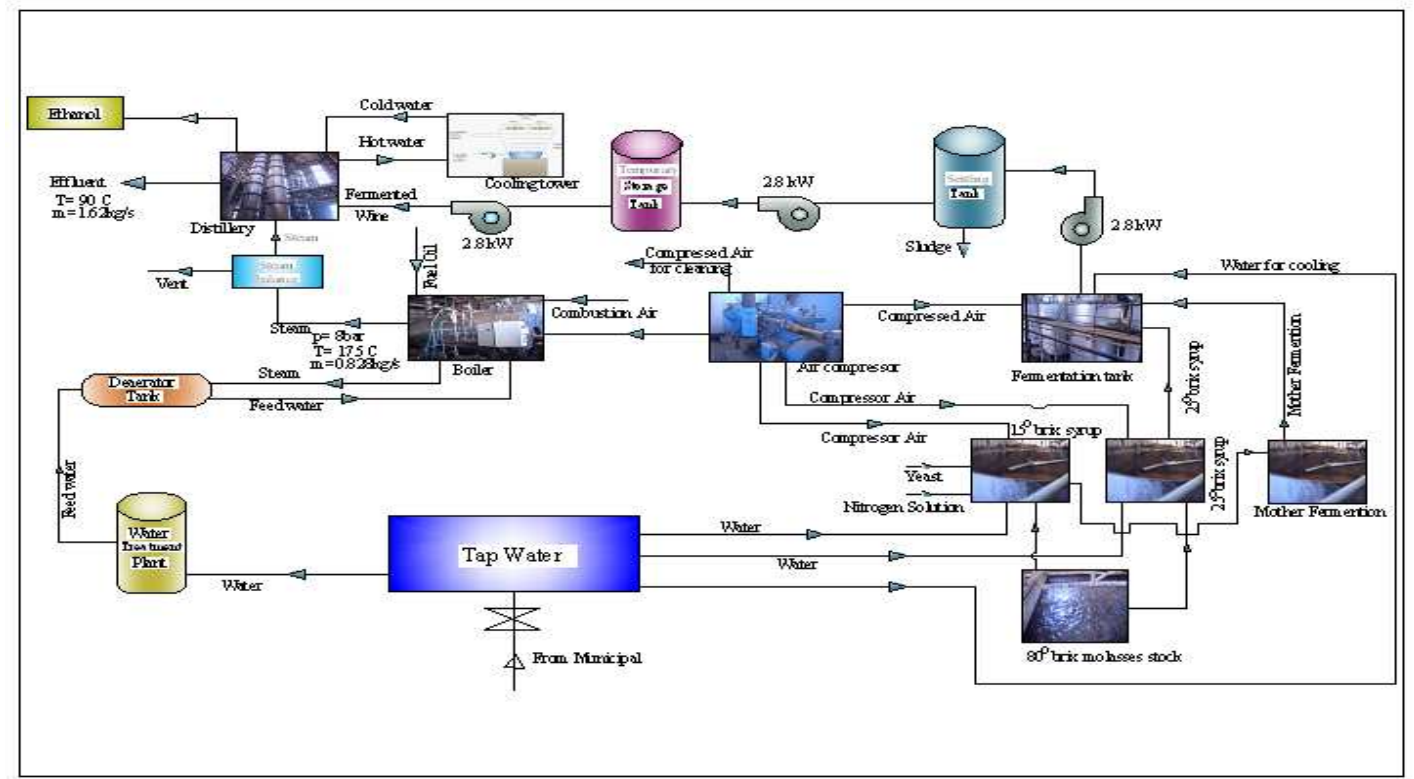

Figure 1: Factory Layout
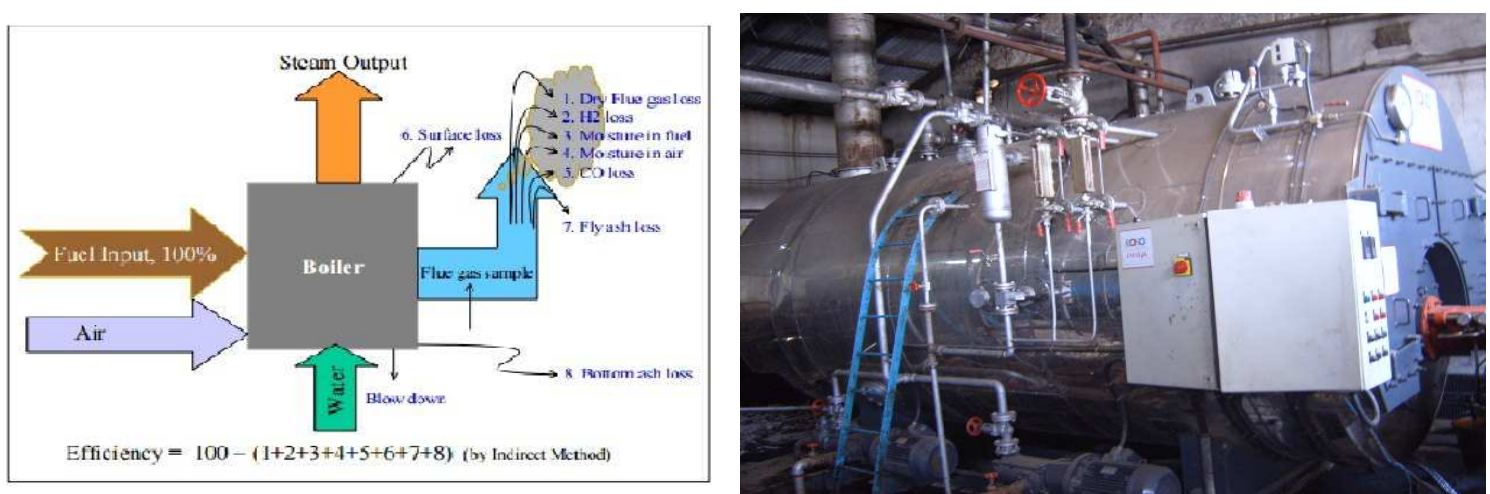

Figure 2: Factory Boiler

The various factors affecting the boiler performance [9,10] are listed below: $f$ Periodical cleaning of boilers, $f$ Periodical soot blowing, $f$ Proper water treatment programme and blow down control, $f$ Draft control, $f$ Excess air control, $f$ Percentage loading of boiler, $f$ Steam generation pressure and temperature $f$ Boiler insulation $f$ Quality of fuel

The data related to steam generation of the boiler were obtained by 
- $\quad$ Direct measurement by portable instruments

- Direct recording from boiler control room

- $\quad$ Referring to factory $\log$ sheets and data record file

- $\quad$ From factory employees

The few instruments used are portable combustion analyzer, infrared and K type thermometer, stopwatch and US flow meter.

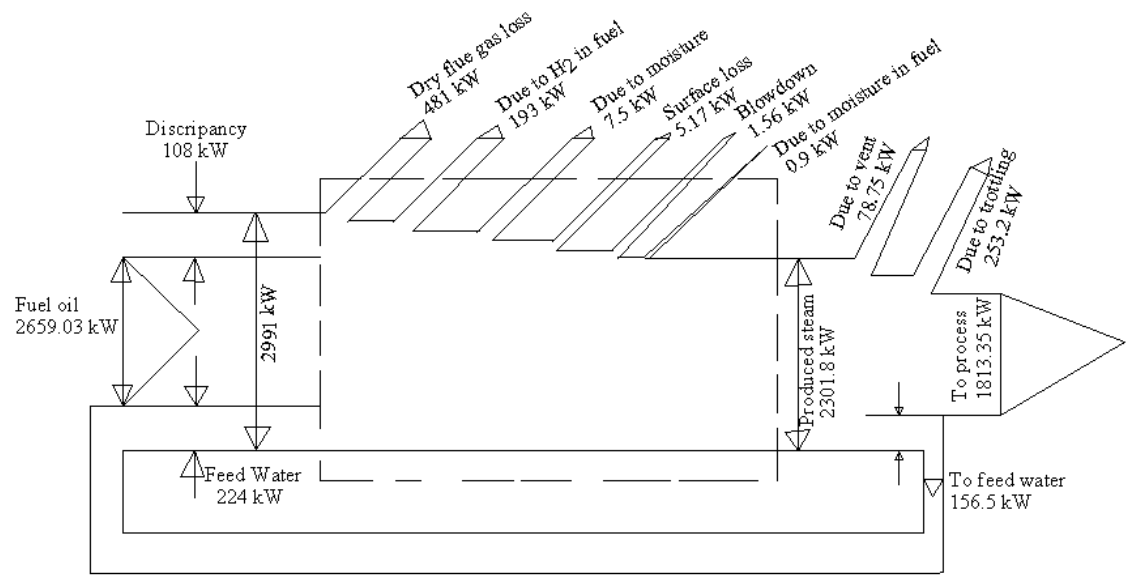

Figure 3: Sankey Diagram of the Boiler

\section{Mass Balance for the Combustion Process}

The mass balance of the combustion process is consisting of actual air supplied and furnace oil as an input mass and excess oxygen, nitrogen, carbon dioxide and sulfur dioxide as an output mass.

Table 3: Energy Balance Sheet

\begin{tabular}{|c|c|c|c|}
\hline No & Input Energy [kW] & No & Output Energy [kW] \\
\hline 1 & Fuel due to its heat content $=2654.3$ & 1 & Heat loss due to dry flue gas $=481$ \\
\hline 2 & Fuel sensible heat $=4.74$ & 2 & $\begin{array}{l}\text { Heat loss due to hydrogen in furnace } \\
\text { oil }=193\end{array}$ \\
\hline 3 & Feed water $=224$ & 3 & $\begin{array}{l}\text { Heat loss due to hydrogen in furnace } \\
\text { oil }=193\end{array}$ \\
\hline 4 & Combustion air $=0$ & 4 & Heat loss due to moisture in air $=7.5$ \\
\hline & \multirow{6}{*}{$\sum_{i=1}^{4}$ Energy Inputs $=2883.04$} & 5 & Heat loss due to moisture in fuel $=0.9$ \\
\hline & & 6 & Surface loss $=5.17$ \\
\hline & & 7 & Blow down loss $=1.56$ \\
\hline & & 8 & $\begin{array}{l}\text { Heat carried away by the steam = } \\
2301.8\end{array}$ \\
\hline & & & $\sum_{1=1}^{7}$ Energy $\quad$ Losses $=2991$ \\
\hline & & & $\sum_{1=1}^{6}$ Energy $\quad$ Losses $=689.13$ \\
\hline
\end{tabular}

\section{Boiler Surface Loss Analysis}

The energy lost from the boiler surfaces, surface temperatures of the boiler 
An Ultra Sound flow meter was used to find the fluid flow through a pipe, ultrasonic flow meter is used. Using this meter the following flow velocities were measured: fuel flow velocity, blow down flow velocity, and feed water flow velocity.

\section{Heating Value of Furnace Oil}

$$
N C V=G C V-\left(M_{H_{2} O}\right) \times h_{f g}
$$

Where $h_{f g}$ - Enthalpy of vaporization of water $=2441.12 \mathrm{~kJ} / \mathrm{kg},\left(M_{\mathrm{H}_{2} \mathrm{O}}\right)$ - Mass of water vapour in the flue gas

$\left(M_{\mathrm{H}_{2} \mathrm{O}}\right)=9 \mathrm{H}(1-\% \mathrm{M})+\% \mathrm{M}, \mathrm{H}$ mass of percent of hydrogen in the furnace oil

$\mathrm{NCV}=41,800 \mathrm{~kJ} / \mathrm{kg}-(1.04 \times 2441.12 \mathrm{~kJ} / \mathrm{kg})=39261.235 \mathrm{~kJ} / \mathrm{kg}$

\section{Analysis of Furnace Oil Combustion}

To find the amount of energy liberated during furnace oil combustion, the following mass and energy analysis of the furnace oil, the combustion air and the combustion products are very important.

\section{Excess Air Supplied (EA)}

The amount of moisture content of the air used for combustion can be found by calculating the absolute humidity. The excess air supplied to the boiler/furnace may be computed using the percentage of oxygen present

Excess air supplied $(\mathrm{EA})=\frac{\mathrm{O}_{2} \%}{21 \%-\mathrm{O}_{2} \%} \times 100 \% \mathrm{O}_{2}$ measured in flue gas $=10.6 \%$ and substitute in $(6.7)$ the excess air is:

$$
\mathrm{EA}=\frac{10.6 \%}{21 \%-10.6 \%}=\mathbf{1 0 2} \%
$$

Substitute (6.8) \& (6.5) in (6.6) the actual air supplied is:

$$
\begin{aligned}
& \mathrm{AA}=[1+102 / 100] \times[13.92]=28.12 \mathrm{~kg} \text { of air } / \mathbf{~ k g} \text { of fuel } \\
& \dot{m}_{\text {flue }}=29.4 \frac{\mathrm{kg} \text { flue }}{\mathrm{kg} g_{\text {fuel }}} \times 0.0635 \frac{\mathrm{kg} \text { fuel }}{\mathrm{sec}}=1.87 \frac{\mathrm{kg} \text { flue }}{\mathrm{sec}}
\end{aligned}
$$

\section{Specific Heat of Dry Flue Gases}

For furnace oil, the specific heat of dry flue gas is given by

$C_{P_{f g}}=\left(0.3+0.000038 T_{\text {furnace }}\right) \mathrm{kcal} / \mathrm{kg}{ }^{o} \mathrm{C}$, Where $T_{\text {furnace }}$ - Furnace temperature

Sp heat of flue gas $=0.323 \mathrm{kcal} / \mathrm{kg}^{O} \mathrm{C}=1.35 \mathrm{~kJ} / \mathrm{kg}^{O} \mathrm{C}$ 


\section{Mass Flow Rate of Furnace Oil}

$\dot{m}_{f}=V_{f} \times A_{f} \times \rho_{f}$ whereas $A_{f}$ - Area of fuel flow pipe

$V_{f}$ - Velocity of fuel flow $=0.0421^{m} / \mathrm{s}, \rho_{f}$ - Density of fuel $=991 \frac{\mathrm{kg}}{\mathrm{m}^{3}}$

D - Diameter of pipe $=0.0508 \mathrm{~m}$

$$
\dot{m}_{f}=0.0635 \frac{\mathrm{kg}}{\mathrm{s}}
$$

\section{Mass Flow Rate of Feed Water}

$$
\stackrel{\bullet}{m_{w}}=V_{w} \times A_{w} \times \rho_{w}
$$

Where $V_{w}$ - Velocity of feed water flow $=0.6403^{m} / s, \rho_{w}$ - Density of water $=1000 \frac{\mathrm{kg}}{\mathrm{m}^{3}}$

$$
\dot{m}_{w}=84,153.6 \mathrm{~kg} / \mathrm{day}
$$

\section{Mass Flow Rate of Blow Down $m_{b}$}

Boiler blow down is one of the major causes of energy loss from boiler drum. In the factory, blow down is done manually by operating a valve fitted with a discharge pipe at the lowest point of the boiler shell. Blow down is done to reduce total dissolved solids (TDS). This is done twice a shift for 5 minutes. The measured velocity, pipe diameter and density are used for calculation

The mass flow rate of blow down $\dot{m}_{b}=V_{b} \times A_{b} \times \rho_{b}$

Where $V_{b}$ - Velocity of blow down flow $=0.112^{m} / s, \rho_{b}$ - Density of blow down $=951 \frac{\mathrm{kg}}{\mathrm{m}^{3}}$

$\mathrm{D}$ - Diameter of the pipe $=0.0508 \mathrm{~m}, \mathrm{t}_{\mathrm{day}}$-Daily total time of blow down

$$
\dot{m}_{b}=291.6 \mathrm{~kg} / \mathrm{day}
$$

\section{Energy Analysis of the Boiler}

To perform the thermal energy audit of the boiler and thereby obtain the first law combustion and boiler efficiency, thermal energy analysis of the boiler must be conducted 


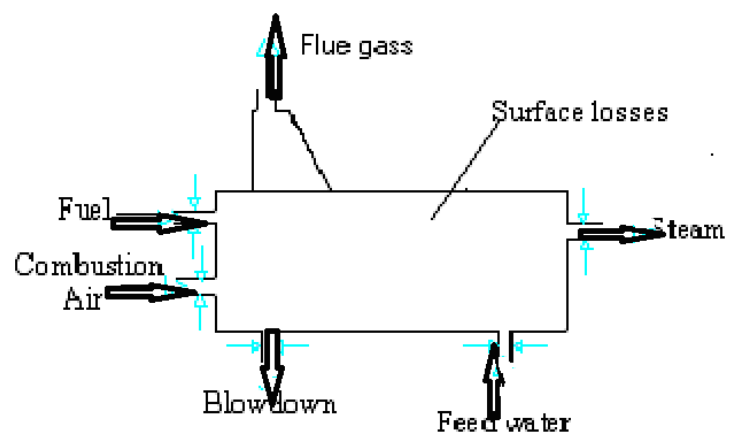

Figure 4: Input and Output of the Boiler

\section{Energy of Furnace Oil}

$$
\begin{aligned}
& Q_{f}=\dot{m}_{f}(G C V)+\dot{m}_{f} \times C_{f} \times\left(T_{f}-T_{a}\right) \\
& 2654.3 \mathrm{~kW}+4.74 \mathrm{~kW}
\end{aligned}
$$

\section{Energy of Feed Water}

The energy of feed water is the enthalpy of water $Q_{w}=\dot{m}_{w} \times C_{w} \times\left(T_{w}-T_{a}\right)$

Where $Q_{w}$ - Energy of feed water, $\dot{m}_{w}$ - Mass flow rate of feed water

$C_{w}$-Specific heat of water $=4.18 \mathrm{~kJ} / \mathrm{kg}^{\circ} \mathrm{C}, T_{w}$ - Temperature of feed water $=80{ }^{\circ} \mathrm{C}$

$T_{a}$-Ambient temperature $=25^{\circ} \mathrm{C}$

$Q_{w}=84,153.6 \mathrm{~kg} / \mathrm{day} * 4.18 \mathrm{~kJ} / \mathrm{kg}^{o} \mathrm{C} *\left(80^{\circ} \mathrm{C}-25^{\circ} \mathrm{C}\right)=\mathbf{2 2 4} \mathbf{k W}$

The energy output (losses) associated with the burning of furnace oil in the combustion chamber and the boiler. The energy loss due to:

- Dry flue gases loss, ii. Heat loss due to evaporation of water, resulted from the formation of $\mathrm{H}_{2}$ in fuel, iii. Heat loss due to moisture content of air

- Heat loss due to radiation and convection from the boiler surface

- Heat loss due to moisture content of the fuel, v. Boiler blow down water from the boiler drum, VI. Useful heat loss of steam.

Dry flue gas loss $\dot{Q}_{\text {flue }}=\dot{m}_{\text {flue }} C_{p}\left(T_{\text {flue }}-T_{a}\right)$

Where

$\mathrm{T}_{\text {flue }}$ - Flue gas temperature $=224^{\circ} \mathrm{C}, T_{a}$ - Ambient temperature $=25^{\circ} \mathrm{C}$ 


$$
\begin{aligned}
& C_{p} \text { - Specific heat capacity of flue gas }=1.35 \frac{\mathrm{kJ}}{\mathrm{kg}^{o} \mathrm{k}}, \dot{m}_{\text {flue }} \text { - Mass flow rate of dry flue gas } \\
& \mathrm{Q}_{\text {flue }}^{\circ}=1.79 \frac{\mathrm{kg}_{\text {dry flue gas }}}{\mathrm{s}} \times 1.35 \frac{\mathrm{kJ}}{\mathrm{kg}^{O} \mathrm{k}}\left(224^{\circ} \mathrm{C}-24^{\circ} \mathrm{C}\right)=\mathbf{4 8 1} \mathbf{k W}
\end{aligned}
$$

\section{Heat Loss due to the Presence of $\mathrm{H}_{2}$ in Fuel}

During the combustion process of the furnace oil the hydrogen contained in it reacts with oxygen and water will be formed. The water formed takes away some of the energy liberated during the combustion process.

$$
Q_{H_{2}}=(M)_{H_{2} O} *\left(\dot{m}_{f}\right)\left[h_{f g @ 25^{\circ} \mathrm{C}}+C_{P}\left(T_{f u}-T_{a m b}\right)\right]
$$

Where $\dot{m}_{f}$ - Mass flow rate of fuel $=0.0635 \frac{\mathrm{kg}}{\mathrm{s}}, \mathrm{M}_{\mathrm{H}_{2} \mathrm{O}}$ - Mass of water per $\mathrm{kg}$ of fuel $=1.08$

$$
h_{f g @ 25^{\circ} \mathrm{C}} \text { - Enthalpy of water }=2441.12 \mathrm{~kJ} / \mathrm{kg}, C_{p} \text { - Specific heat capacity }=1.88 \frac{\mathrm{kJ}}{\mathrm{kg}^{o} \mathrm{k}}[4]
$$

$T_{f l u}$ - Flue gas temperature $=224^{\circ} \mathrm{C}, T_{a m b}$-Ambient temperature $=22^{\circ} \mathrm{C}$

$=1.08 \mathrm{~kg}$ water $/ \mathrm{kg}$ fuel $* 0.0635 \frac{\mathrm{kg}}{\mathrm{s}}\left[2441.12 \mathrm{~kJ} / \mathrm{kg}+1.88 \frac{\mathrm{kJ}}{\mathrm{kg}^{\mathrm{O}} \mathrm{k}}\left(224^{\circ} \mathrm{C}-24^{\circ} \mathrm{C}\right)\right]$

$$
=193 \mathrm{~kW}
$$

\section{Heat Loss Due to Moisture Content of Air}

The air used for combustion under standard condition contains moisture. The energy loss due to moisture content of the air is similar to the moisture content of the furnace oil described above

$$
Q_{m o i}=A A S * \gamma_{A} *\left(\dot{m}_{f}\right)\left[C_{P}\left(T_{f u}-T_{a m b}\right)\right]
$$

Where AAS - Actual air supplied $28.12 \mathrm{~kg}$ of air / $\mathrm{kg}$ of fuel

$\gamma_{\mathrm{A}}=0.01211 \mathrm{~kg}$ of $\mathrm{H}_{2} \mathrm{O} / \mathrm{kg}$ of dry air

$=28.12 \mathrm{~kg}$ of air $/ \mathrm{kg}$ of fuel $* 0.01211 \mathrm{~kg}$ of $\mathrm{H}_{2} \mathrm{O} / \mathrm{kg}$ of dry air $* 0.0635 \frac{\mathrm{kg}}{\mathrm{s}} *$

$$
\left[1.88 \frac{k J}{k g^{o} k}\left(224^{\circ} \mathrm{C}-25^{\circ} \mathrm{C}\right)\right]
$$

$=7.5 \mathrm{~kW}$

\section{Heat Loss Due to Moisture Present in Fuel}

During combustion process of the furnace oil, due to the presence of moisture in it water will be formed. 
$Q_{M}=(M) *\left(\dot{m}_{f}\right)\left[h_{f g @ 25^{\circ} C}+C_{P}\left(T_{f l u}-T_{a m b}\right)\right]$

Where

$\dot{m}_{f}$ - Mass flow rate of fuel $=0.0635 \frac{\mathrm{kg}}{\mathrm{s}}, M-$ Moisture in fuel $=0.5 \%$

Enthalpy of water $=2441.12 \mathrm{~kJ} / \mathrm{kg}, C_{p}$ - Specific heat capacity $=1.88 \frac{\mathrm{kJ}}{\mathrm{kg}^{O} \mathrm{k}}[4]$

$\mathrm{T}_{\text {flue- }}$ Flue gas temperature $=224^{\circ} \mathrm{C}, T_{\text {amb }}$-Ambient temperature $=25^{\circ} \mathrm{C}$

$=0.005 * 0.0635 \frac{k g}{s}\left[2441.12 \mathrm{~kJ} / \mathrm{kg}+1.88 \frac{\mathrm{kJ}}{\mathrm{kg}^{\circ} \mathrm{k}}\left(224^{\mathrm{O}} \mathrm{C}-25^{\circ} \mathrm{C}\right)\right]$

$=0.9 \mathrm{~kW}$

\section{Heat Loss Due to Radiation and Convection From the Boiler Surface}

As wind cruses over the boiler surface, energy will be lost from the boiler surface to the wind by convection.

$Q_{(i) s}=\left\{0.548\left[\left(T_{(i) s} / 55.55\right)^{4}-\left(T_{(i) a} / 55.55\right)^{4}\right]+1.957\left(T_{(i) s}-T_{(i) a}\right)^{1.25} \sqrt{\frac{196.85 V+68.9}{68.9}}\right\} \frac{w}{m^{2}} * S_{(i) A}$

Where

$\mathrm{T}_{\mathrm{s}}$ - Surface temperature for front, cylindrical and back is $380.7^{\mathrm{O}} \mathrm{k}, 304{ }^{\mathrm{O}} \mathrm{k}$ and $315^{\mathrm{o}} \mathrm{k}$ respectively.

V- Wind velocity $=2.56 \mathrm{~m} / \mathrm{s}$

$\mathrm{T}_{\mathrm{a}}$ - Local ambient temperature for front, cylindrical and back is $305^{\circ} \mathrm{k}, 299^{\circ} \mathrm{k}$ and $300.5^{\circ} \mathrm{k}$ respectively.

$\mathrm{S}_{\mathrm{A}^{-}}$Surface area for front, cylindrical and back is $2.41 \mathrm{~m}^{2}, 24.74 \mathrm{~m}^{2}$ and $2.41 \mathrm{~m}^{2}$ respectively.

$$
\begin{aligned}
& Q_{(i) S}=Q_{\text {Front }}+Q_{\text {Cylinder }}+Q_{\text {Back }} \\
= & 3.37 \mathrm{kw}+1.35 \mathrm{kw}+0.45 \mathrm{kw} \\
= & 5.17 \mathrm{Kw}
\end{aligned}
$$

\section{Boiler Blow Down Water from the Boiler Drum}

The factory use tap water as feed water to the boiler. As it is already discussed, the water contains impurities.

$$
Q_{b}=\dot{m}_{b} \times h_{f @ 110^{\circ} \mathrm{C}}
$$

Where $h_{f @ 110^{\circ} \mathrm{C}}$ - Enthalpy of blow down $=461.3 \mathrm{~kJ} / \mathrm{kg}$

$\dot{m}_{b}$ - Mass flow rate of blow down $=291.6 \mathrm{~kg} / \mathrm{day}$ 
$=291.6 \mathrm{~kg} /$ day $x 461.3 \mathrm{~kJ} / \mathrm{kg}$

$=1.56 \mathrm{~kW}$

\section{The Heat Carried Away by the Steam}

One of the major energy output is the heat carried away by the steam. The amount of heat energy carried away by the steam is obtained by multiplying the amount of steam produced per second by the enthalpy.

$Q_{s}=\dot{m_{s}} \times h_{g s} Q_{s}$-Heat carried away by the steam

Where $m_{s}$ - Mass flow rate of steam $=83,862 \mathrm{~kg} /$ day

$h_{g s}$-Enthalpy of super heated steam at a temperature of $175{ }^{\circ} \mathrm{C}$ and pressure $8 \mathrm{bar}=2779.95 \frac{\mathrm{kJ}}{\mathrm{kg}}$

$Q_{s}=83,862 \mathrm{~kg} /$ day $* 2779.95 \frac{\mathrm{kJ}}{\mathrm{kg}} \quad Q_{s}=\mathbf{2 3 0 1 . 8} \mathbf{k W}$

\section{Analysis of Energy Loss Due to Vent Steam}

$$
\begin{aligned}
& Q_{v}=\dot{m}_{V} \times h_{f v @ 125{ }^{\circ} \mathrm{C}} \\
& \text { Where } \dot{m_{V}}-\text { Mass flow rate of vent steam }=0.15 \frac{\mathrm{kg}}{\mathrm{s}}(6.23) \\
& h_{f V @ 125{ }^{\circ} \mathrm{C}}-\text { Enthalpy of vent steam }=524.99 \frac{\mathrm{kJ}}{\mathrm{kg}{ }^{o} k} \\
& Q_{v}=0.15 \frac{k g}{s} * 524.99 \frac{k J}{k g{ }^{o} k} \\
& =78.75 \mathrm{~kW} \\
& Q_{v}=78.75 \mathrm{~kW}
\end{aligned}
$$

\section{Analysis of Energy Loss Due to Throttling}

The factory is reduced the produced steam temperature and pressure from $175{ }^{\circ} \mathrm{C}$ and 8 bar to different temperature and pressure $Q_{t}=\dot{m_{s}} \times \sum \Delta h_{g s}$

Where

$$
\begin{aligned}
& \sum \Delta h_{g s}=\sum \text { Enthalpy@ produced Steam-Enthalpy@ Each column Required } \\
& =305.75 \frac{\mathrm{kJ}}{\mathrm{kg}}
\end{aligned}
$$




\section{Efficiency of the Boiler Based on Input-Output Method}

In this method the energy gains of the working fluid (feed water and steam) are compared with the energy content of the boiler fuel. This is also known as 'input-output method'

$$
\begin{aligned}
& \text { Boiler efficiency } \eta=\frac{\dot{m s}\left(h_{g s}-h_{f s}\right)}{\dot{m}_{f}(G C V)} \\
& \eta=\frac{0.828 \frac{k g}{s}\left(2779.95 \frac{k J}{k g}-384.91 \frac{k J}{k g}\right)}{0.0635 \frac{k g}{s}\left(41800 \frac{k J}{k g}\right)} \eta=74.71 \%
\end{aligned}
$$

\section{Energy Efficiency of the Boiler Based on Heat Loss Method}

The heat balance efficiency measurement method is based on accounting of all the heat losses of the boiler.

\section{Thermal Efficiency of the Boiler}

The thermal efficiency of the boiler based on heat loss method on GCV is given by

$$
\begin{aligned}
& \eta_{\text {thGCV }}=\left[\begin{array}{cc}
1-\frac{\sum_{i=1}^{6} \text { Energy }}{\text { Losses }} \\
\sum_{i=1}^{4} \text { Energy } & \text { Input }
\end{array}\right] x 100 \% \\
& =\left[1-\frac{689.13 \mathrm{~kW}}{2883.04 \mathrm{~kW}}\right]=\mathbf{7 6 . 1 \%}
\end{aligned}
$$

\section{Combustion Efficiency of the Boiler}

The combustion efficiency of the furnace based on heat loss method on GCV is given by

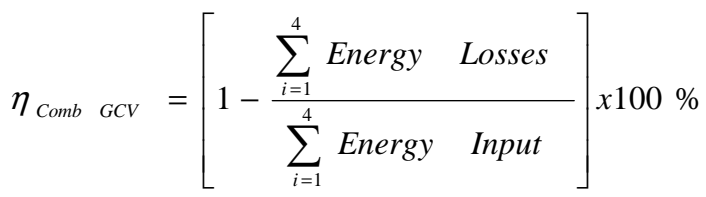

$$
\begin{aligned}
& =\left[1-\frac{682.4 \mathrm{~kW}}{2883.04 \mathrm{~kW}}\right] \times 100 \%=\mathbf{7 6 . 3 \%}
\end{aligned}
$$

\section{Estimation of Boiler Shell Losses}

As it is clearly indicated in the heat balance sheet and conclusion remarks of the boiler, the summation of energy input to boiler and the summation of energy output are not equal.

$$
\begin{aligned}
& \left(Q_{\text {shell }}\right)_{G C V}=\eta_{\text {th }}\left(\sum_{i=1}^{7} \text { Energy Losses }-\sum_{i=1}^{4} \text { Energy Input }\right) \\
& \left(Q_{\text {shell }}\right)_{G C V}=0.761(2991 \mathrm{~kW}-2883.04 \mathrm{~kW})=\mathbf{8 2 . 1 6} \mathbf{k W}
\end{aligned}
$$




$$
\begin{aligned}
& \eta_{\text {overall }}=\left[\begin{array}{cccc}
1-\frac{\sum_{i=1}^{6} \text { Energy }}{\text { Losses }} & \left.+Q_{\text {Shell }} \text { (GCV }\right) \\
\sum_{i=1}^{4} \text { Energy } & \text { Input }
\end{array}\right] \times 100 \% \\
& \eta_{\text {Overall }}=\left[1-\frac{689.13 k W+82.16 k W}{2883.04 k W}\right] x 100 \%=73.2 \%
\end{aligned}
$$

The energy efficiency of the boiler of the factory is found to be $71.4 \%$. This efficiency is less than the expected performance of a new furnace oil fired boiler, which is equal to 85\% [4]. The main causes that contribute to the significant drop in efficiency of the boiler is the energy loss due to

Dry flue gas loss $(16.15 \%)$

Hydrogen in furnace oil $(6.41 \%)$

Moisture in combustion air $(0.251 \%)$

Blow down (0.0521\%)

Boiler shell loss $(2.9 \%)$

Moisture in fuel $(0.0334 \%)$

This study indicates the possible ECO as discussed below.

\section{List of $\mathrm{ECO}_{\mathrm{S}}$ Identified from Audit Analysis}

From detailed energy audit conducted, the following list of energy conservation opportunities is found:

- The flue gas temperature is greater than the recommended range due to the absence of an economizer

- Due to the failure of water treatment plant, the boiler operates with significant shell energy losses.

- The combustion efficiency of the boiler is low due to a large percent of excess air is admitted to the combustion chamber.

- The total steam demand of the factory is $2.13 \mathrm{ton} / \mathrm{hr}$, but the boiler was designed to produce 3 ton/hr. The extra amount of the produced steam is removed by means of venting and throttling, therefore the boiler is oversized.

\section{Calculation of the Combustion Efficiency at 15\% Excess Air}

Equation using the combustion efficiency of the furnace at $15 \%$ of excess air is given by

$$
\eta_{\text {Comb GCV }}=\left[1-\frac{\sum_{i=1}^{4} \text { Energy Losses }}{\sum_{i=1}^{4} \text { Energy Input }}\right] x 100 \%=\mathbf{8 1 . 3 5 \%}
$$

\section{Lists of Technically Feasible ECOs}

- Repairing water treatment plant

- Controlling the excess air by reducing fan motor power 
- Replacing the boiler with proper sized

The energy of fuel that could be saved by repairing the water treatment plant is given by Equation. The energy that can be saved by minimizing shell energy loss due to pre-treated feed water and mechanically cleaning the shell (water side) is given

$$
\text { Energy saved }=\dot{m}_{f} G C V\left(\eta_{t h}-\eta_{\text {overall }}\right)=0.0635 \frac{\mathrm{kg}}{\mathrm{s}} \times 41,800 \frac{\mathrm{kJ}}{\mathrm{kg}}[0.76-0.732]
$$

$=79.63 \mathrm{~kW}$

$$
\eta_{\text {overall }}=\left[1-\frac{689.13 \mathrm{~kW}+2.5 \mathrm{~kW}}{2883.04 \mathrm{~kW}}\right] x 100 \%=\mathbf{7 6 \%}
$$

Therefore the increased efficiency is $=76 \%-73.2 \%=\mathbf{2 . 8} \%$

\section{Implementation Cost}

According to factory cost analysis the estimated cost for repairing their water treatment plant is ranges from 20,000birr - 30,000 birr. And the cost of a typical rotating cleaning equipment for fire tube boilers ranges from $\$ 3,000$ $\$ 5,000(27,600-46,000$ Birr $)$ depending on size and feature.

\section{Payback Period}

The simple payback period can be found by dividing the cost saved with the cost of repairing water treatment plant and cleaning equipment

Simple payback Period $=$ Implementation Cost $/$ Cost Saved (6.49)

$$
\begin{aligned}
& =98,196 \mathrm{Birr} / 207,543 \mathrm{Birr} \\
& =0.473 \text { year } \cong 6 \text { months }
\end{aligned}
$$

\section{Evaluation of Controlling the Excess Air by Reducing Motor Capacity}

$$
\begin{aligned}
\text { Energy saved } & =\dot{m}_{f} \times G C V\left[\eta_{(\text {cumb }) 15 \%}-\eta_{(\text {comb }) a c t u a l}\right] \\
& =0.0635 \frac{\mathrm{kg}}{\mathrm{s}} \times 41,800 \frac{\mathrm{kJ}}{\mathrm{kg}}[0.8135-0.7624]=\mathbf{1 3 5 . 6 3 \mathbf { k W }}
\end{aligned}
$$

The equivalent amount of fuel and money saved is 84,704.69 litre and 352,820.44 birr per year

\section{Evaluation of Replacing the Boiler}

\section{Saving Analysis}

The energy saved by replacing the existing boiler is given by

$$
\text { Energy Saved }=\dot{m}_{s(\text { saved })} \times h_{g @ 8 b a r \& 175^{\circ} C} \times \eta_{\text {Comb @15\% excess air }}(6
$$


But $\dot{m}_{s(\text { saved })}=($ Steam produced - Steam demand $)$

Taking $10 \%$ margin on steam demand $=2.13 \times 1.1=2.343 \mathrm{ton} / \mathrm{hr}$

$=(3 \mathrm{ton} / \mathrm{hr}-2.343 \mathrm{ton} / \mathrm{hr})=0.657 \mathrm{ton} / \mathrm{hr}=0.183 \mathrm{~kg} / \mathrm{s}$

Substituting the above data in Equation (6.58) the saving energy is

$=0.183 \frac{\mathrm{kg}}{\mathrm{s}} \times 2779.95 \frac{\mathrm{kJ}}{\mathrm{kg}} \times 0.8135$

$=413.85 \mathrm{~kW}$

The equivalent litre of fuel and money saved is 258,957.27litre and 1,078,634.5 Birr per year respectively.

\section{Payback Period}

The simple payback period can be found by dividing the cost saved with the cost of the boiler. Adding 47\% [15] additional cost of the direct maximum cost of purchasing the boiler for transportation and other related costs, the cost of having new boiler will be 1.47 x 2,760,000 =4,057,200 Birr.

Subtract the salvage value the implementation cost will be $=2,057,200 \mathrm{Birr}$

Simple payback Period $=$ Implementation Cost $/$ Cost Saved

$=2,057,200$ Birr / 1,078,634.5Birr

$=1.9$ years

\section{CONCLUSIONS}

\section{Summary of the Energy Saving Recommended and Priority}

The Energy audit concludes that the possible ECOs' for water treatment plant, motor replacement of a new boiler to meet the demand of the factory production. The cost saved is as given below;

According to the energy study conducted for the boiler, the increased efficiency of water treatment plant is by $2.8 \%$, the increased efficiency of the boiler by $3.7 \%$ and the energy saved by erecting suitable boiler is $413.58 \mathrm{~kW}$, the saving is by $52 \%$ and considerable cost saving is nearly one million Birr /year [41,670 USD]

- Repairing water treatment plant,

- Keeping the percentage of the excess air within the recommended range, and

- $\quad$ Replacing the existing boiler with proper sized boiler

The payback period the maximum of 2 years

\section{ACKNOWLEDGEMENT}

The authors would like to thank the company authorities of the Mechannissa Alcohol factory, Addis Ababa and ASTU, Adama for permitting and extending their fullest co-operation during this audit. 
Table 4

\begin{tabular}{|c|l|c|c|c|c|c|}
\hline $\begin{array}{c}\text { SI. } \\
\text { No. }\end{array}$ & \multicolumn{1}{|c|}{$\begin{array}{c}\text { Types of Energy Saving } \\
\text { Recommendation }\end{array}$} & $\begin{array}{c}\text { Increasing } \\
\text { Efficiency } \\
(\boldsymbol{\%})\end{array}$ & $\begin{array}{c}\text { Yearly } \\
\text { Saving (Birr) }\end{array}$ & $\begin{array}{c}\text { Capital } \\
\text { Investment } \\
(\mathbf{B i r r})\end{array}$ & $\begin{array}{c}\text { Simple } \\
\text { Payback } \\
\text { (Year) }\end{array}$ & Priority \\
\hline 1 & Repairing water treatment plant & 3.7 & 207 & 98,196 & 0.473 & $2^{\text {nd }}$ \\
\hline 2 & Replacing the existing boiler & - & 1.078 million & $0.4,05$ million & 3.77 & $1^{\text {st }}$ \\
\hline 3 & $\begin{array}{l}\text { Controlling excess air by reducing } \\
\text { fan motor capacity }\end{array}$ & 5.1 & 0.352 million & $20,868.96$ & 0.06 & $3^{\text {rd }}$ \\
\hline
\end{tabular}

\section{REFERENCES}

1. Barney L.Capehart, ph.D, CEM; Guide to Energy management, 2nd edition

2. http//:www.Bureau of Energy Efficiency: Performance Analysis of Boiler.pdf

3. www.em-ea.org/GuideBooks/Books-1/13:Combustion Analysis.pdf

4. Dr. G.G.Raian /Cochin/India: Energy Saving in Steam System

5. Energy Efficiency Handbook, prepared by the Council of Industrial Boiler Owners (CIBO), edited by Ronald A. Zeitz, November 1997

6. Energy Efficiency Project Management Handbook, Organized by California energy commission, California, 2000

7. Ms. Shardha Chandrakant Deshmukh, Ms. Varsha Arjun Patil, "Energy Conservation and Audit," International journal of Scientific and research Publication, Vol 3,Issue 8,Aug 2013

8. Chayalakshmi C. L et al., Hybrid Time Series Analysis and Forecasting of Boiler Efficiency, International Journal of Electronics, Communication \& Instrumentation Engineering Research and Development (IJECIERD), Volume 6, Issue 1, February 2016, pp. 1-8

9. Swati Khare, Abhay Kumar Sharma, Ranjan. R.K, Shashank Khare," Energy Conservation through Energy Audit", International Journal of Current Research, Vol4, issue-09, pp 144 to 148 Sep 2012.

10. Industrial Training on Energy Efficiency, Organized by the Ethiopian Society of Chemical Engineers in collaboration with Chemical Engineering Department, AAU, 2006

11. Sachin P. Parthe, Santosh Kompeli,” Energy Audit and Conservation Tool for Energy Efficiency“, International Research Journal of Engineering and Technology (IRJET) e-ISSN: 2395 -0056 Volume: 02 Issue: 08 | Nov-2015. 
